\title{
Landscape reading methodology of urban forests: interpreting past and current socioecological interactions in Rio de Janeiro
}

Metodología de lectura del paisaje en bosques urbanos: interpretando el pasado y las interacciones socioecológicas actuales en Rio de Janeiro DOI: 10.5935/2237-2717.20160011

\author{
Alexandro Solórzano \\ Pontifícia Universidade Católica Rio de Janeiro \\ alexandrosol@gmail.com \\ Rio de Janeiro \\ Brasil \\ Rogério Ribeiro de Oliveira \\ Pontifícia Universidade Católica Rio de Janeiro \\ rro@puc-rio.br \\ Adi Estela Lazos-Ruiz \\ Pontifícia Universidade Católica Rio de Janeiro \\ adita lazos@yahoo.co.uk
}

Recibido: 16 de marzo de 2016

Aprobado: 12 de junio de 2016

\section{ABSTRACT}

The landscapes of Rio de Janeiro are a product of a long history of the society interacting with the forest, with the legacies of this historical interaction being imprinted and hidden within the vegetation cover. Reading this landscape requires the following steps: 1) a comprehensive history of the process of human occupation and land uses; 2) revealing, through material evidence past human uses; 3) deciphering current ecological change, through species structure and composition (exotic species, different assemblage patterns). The requirements to accomplish these steps stem from field knowledge mainly from geography and ecology, and archival knowledge in researching historical documents. Here we highlight the importance of a multi-scalar approach, reading the landscape from a broad perspective using GIS and satellite imagery to understand the spatial distribution of the physical, ecological and social elements of the landscape.

\section{KEYWORDS}

Socioecological systems, environmental history, landscape transformations.

\section{RESUMEN}

Los paisajes de Rio de Janeiro son producto de una larga historia de los humanos interactuando con el bosque, los legados de esta interacción histórica están marcados y escondidos dentro de estos paisajes complejos. Leer este paisaje requiere los siguientes pasos: 1) una revisión histórica completa de los procesos de ocupación humana y usos del suelo; 2) descifrar los usos humanos pasados a través de la evidencia material; 3) descifrar los cambios ecológicos a través de la composición de especies (especies exóticas, diferentes patrones en las comunidades de especies). Los requerimentos para alcanzar estos pasos incluyen conocimiento de campo, principalmente de geografía y ecología, así como investigación de documentos históricos. En este trabajo resaltamos la importancia del enfoque multiescalar, leyendo el paisaje desde una perspectiva global usando SIG e imágenes de satélite para entender la distribución espacial de los elementos físicos, ecológicos y sociales del paisaje.

\section{Palavras clave}

Sistemas socioecológicos, historia ambiental, transformaciones del paisaje. 


\section{Introduction}

Since our pre-history humans have interacted in many different ways with their surrounding environments, thus being an intrinsic part of its transformation process. After the industrial revolution, the increasing interactions of people with different ecosystems became more complex and in many cases more destructive. ${ }^{1}$ Ecosystem resilience, especially of its structure and functionally became increasingly adaptive to different land use histories. Thus, these complex landscapes can be better understood, not only through a static assessment of the elements that compose it, but also through an understanding of the historical legacies of human use and occupation. Even though many forest remnants in the tropics are currently free of human presence, it is quite notable the historical legacies hidden beneath the leaf litter, embedded in the structure through modification of physical features (e.g. slopes, streams, basins), abandoned ruins and tools lost in the dense forest and even in the subtle changes in vegetation attributes through modification of structure and composition. ${ }^{2}$

Other important legacies include more intangible elements, such as the lack of fauna, a process that has its roots in Amerindian history, as megafauna extinction of the Pleistocene is directly connected to over hunting by primitive human groupings in the Americas. ${ }^{3}$. This initial ecosystem modification was followed by a more profound process of landscape transformation dated to the first European settlers arriving in the Brazilian Atlantic coast. ${ }^{4}$ All of these aforementioned human legacies are a result of a complex history of humans interacting with their environment, throughout different historical periods with different implications, which in the present are clustered together in these complex landscapes.

Currently the spatial dynamics of the city of Rio de Janeiro have gone through intense modifications due to the mega events such as the 2016 Olympics. Of the various places in Rio that will harbor an olympic activity the Lagoa Rodrigo de Freitas stands out due to its location, touristic value and socioecological history. Reading landscapes is a multipart activity of observation and investigative work, finding hints and signs from the past to bring about light over these complexities in the present. Here we are proposing an interdisciplinary landscape reading method that encompasses a theoretical background of geography and environmental history through the study of the society-nature relation coupled with the novel ecosystem concept, from restauration ecological thought. This proposal is largely built on the understanding of humans as part of nature, connected by processes currently developed through social metabolism and socioecological systems theory frameworks.

\section{Methods}

\section{Study Area: Lagoa Rodrigo de Freitas basin}

The city of Rio de Janeiro in Brazil, is located in the southeastern portion of the Atlantic Forest biome. It has a long history of human interactions with the forest ecosystems, currently

\footnotetext{
${ }^{1}$ Will Steffen, Paul Crutzen and John McNeill, "The Anthropocene: are humans now overwhelming the great forces of nature," AMBIO: A Journal of the Human Environment 36 (2007): 614-621.

${ }^{2}$ Rogério Oliveira, Joana Stingel and Dean Berck, "Uma floresta de vestígios: metabolismo social e a atividade de carvoeiros nos séculos XIX e XX no Rio de Janeiro, RJ," Revista Internacional Interdisciplinar INTERthesis 8 (2011): 286315.

${ }^{3}$ Fernando Fernandez and Bernardo Araújo, "As primeiras fronteiras: impactos ecológicos da expansão humana pelo mundo", in História Ambiental: Fronteiras, Recursos Naturais e Proteção da Natureza, org. José Luiz de Andrade et al. (Rio de Janeiro: Garamond, 2012), 97-117.

${ }^{4}$ Rogério Oliveira and Alexandro Solórzano, "Três Hipóteses Ligadas à Dimensão Humana da Biodiversidade da Mata Atlântica," Fronteiras: Sociedade, Tecnologia e Meio Ambiente 3 (2014): 80-95.
} 
isolated in two rather large coastal massifs (maciços) and small hills/mountains (morros): Pedra Branca and Tijuca Massif. Rio holds the world's largest urban forest and has a population of more than 6,3 million inhabitants. ${ }^{5}$

The hydrological basin of Lagoa Rodrigo de Freitas is located in the southern zone (Zona Sul) of Rio de Janeiro (Figure 1) encompassing part of the Tijuca Massif. It occupies an area of 2,345.4 ha, with an altitude gradient of 0 to 710 above sea level, that extends from the coastal line -Ipanema and Leblon beaches- to the top of the Serra da Carioca (Carioca range); being the highest point the summit of Corcovado where the monument Cristo Redentor stands. The lowland contains the coastal lagoon (Lagoa) Rodrigo de Freitas. Of the basin's total area, $34 \%$ is urbanized and $46 \%$ is covered by forests, ranging from early successional (urban-forest border communities) to intermediate and advanced successional stages. The remaining cover is distributed among other classes such as other woody anthropogenic vegetation (5.3\%), continental bodies of water $(9.8 \%)$, and rock outcrop $(1.6 \%)^{6}$

The region is well known for its touristic value, containing some of the most important sights of Rio de Janeiro, as aforementioned (Figure 2). Other natural monuments are the Dois Irmãos mountain and Cabritos mountain, two very large gneiss monoliths, which shelter municipal parks, recreational areas, and residential areas. The demographic density of the zone is very high, it has the highest real estate values in the city alongside impoverished and infrastructure-lacking areas tucked in the hills and mountainous areas, of increasing level of risk for human occupation (favelas). These spaces of exclusion are part of the historical legacy of a city filled with spatial contradictions that give place to currently intense socioecological dynamics. ${ }^{7}$ Clues hidden within the landscape help in the reconstruction of the history of past uses and landscape transformation of this basin, shedding important light on current socioecological conflicts surrounding exotic species introduction, natural resource use, human habitation and nature conservation policy.

\section{Landscape Reading methodology: general guidelines}

The landscapes of Rio de Janeiro are a product of a long history of humans interacting with the forest, with the legacies of this historical interaction being imprinted and hidden within these complex landscapes that are even now in constant change. Reading this landscape requires the following steps: 1) a comprehensive history of the process of human occupation and land use; 2) deciphering, through material evidence (ruins, charcoal) past human uses; 3) deciphering current ecological change, through species composition (exotic species, different assemblage patterns). The requirements to accomplish these steps stem from field knowledge mainly from geography and ecology and archival knowledge in researching historical documents. GIS (Geographic Information Systems), the use of satellite images, and aerial photography are fundamental in this landscape analysis in order to have a better understanding of the spatial context, giving an understanding of how physical features of the land, vegetation cover and land use vary throughout space and are interconnected. Through an understanding that water availability and terrain play a fundamental part in human occupation process and resource usage of a landscape, hydrological basins establish a good basis to delimit a spatial extent for the landscape reading method.

\footnotetext{
${ }^{5}$ Dalva Matos, Junius Santos and Diogo Chevalier, "Fire and restoration of the largest urban forest of the world in Rio de Janeiro, Brazil," Urban Ecosystems 6 (2002): 151-161.

${ }^{6}$ SIGFloresta. Secretaria Municipal de Meio Ambiente, last modified December 8, 2011, http://www.rio.rj.gov.br/web/smac/sig-floresta:

${ }^{7}$ Mauricio Abreu, Evolução urbana do Rio de Janeiro (Rio de Janeiro: Instituto Pereira Passos, 2013).
} 


\section{(1) A comprehensive history of the process of human occupation and land use}

The first step in this methodological approach of landscape reading begins with a thorough investigation of the process of human occupation and land use of such given landscape. This starts with a good bibliographic review of existing literature, within the scope of the study area and, when possible, an archival research to further investigate historiographical relationships of the diverse array of social actors that interacted with the physical and ecological setting. Here we exemplify with as specific spatial extent: the landscape encompassed by the Lagoa Rodrigo de Freitas hydrological basin.

The history of land uses in the Lagoa Rodrigo de Freitas basin (LRF basin) is ancient and diverse. Before the arrival to Brazil of the European colonists in the $16^{\text {th }}$ century, the region was occupied by native populations, first of hunter-gatherer populations that left an archaeological legacy of shell mounds (sambaqui) $)^{8}$ and later of hunting and farming Tupinambá groups. ${ }^{9}$ The latter lived in small groups with a nomadic regime, depending mostly on the natural resources availability. They located their settlements near water sources and forests as they lived by means of fishing, hunting, gathering, and agriculture. ${ }^{10}$ Therefore, the LRF basin was very valuable due to its abundant water springs draining from the Sierra, the abundant resources in and around the lagoon (mainly fish and wood), the vast amount of forest resources and proximity to the ocean, all of which contributed to this territory being highly sought out and of great value. After the arrival of European settlers (mostly Portuguese) to the region, and brutal massacre of the indigenous populations, the land was used mostly for sugar cane plantations and mills for sugar and cachaça (distilled from sugar cane) production in the lowland areas close to the lagoon. The success of this activity depended mostly on slave work. There was also a fair amount of subsistence agriculture, especially of cassava (Manihot esculenta Crantz) in slash-and-burn land systems, some livestock activity and forest exploitation (for tools, firewood and charcoal).$^{11}$ The sugar cane mills needed a great amount of forest resources such as wood and firewood, both for the functioning of the mill and for the manufacture of containers to transport the sugar abroad. Therefore a significant portion of the woody vegetation of the Carioca Sierra was consumed (lowland and sub montane broadleaf evergreen forest), as well as the mangroves from the LRF margins.

After more than two centuries of sugar cane production, the lands were expropriated when the Portuguese Empire settled down in Brazil in 1808. The Empire had new needs and the LRF basin offered optimal conditions for the establishment of a gunpowder factory and for an acclimatization garden (later the Botanical Garden) - to test the possibility of survival of economically interesting plants - due to its abundant water resources. ${ }^{12}$

Until the $17^{\text {th }}$ century, the human occupation in the Tijuca Massif was limited to the foothills of the mountains, and the upper parts of the slopes were only explored in the following century. ${ }^{13}$ The city's central area was closer to Guanabara Bay, in another basin,

\footnotetext{
${ }^{8}$ Rogério Oliveira, Massimo Bovini, Angela Buarque and Rita Scheel-Ybert, "Uma cápsula do tempo: o uso potencial de recursos naturais por visitantes pré-coloniais no arquipélago das Cagarras, Rio de Janeiro," Historia Ambiental Latinoamericana y Caribeña 4 (2015).

${ }^{9}$ Rogério Oliveira and Alexandro Solórzano, Três Hipóteses Ligadas à Dimensão Humana, 2014.

${ }^{10}$ Florestan Fernándes, A organização social dos Tupinambá (São Paulo: Editora Hucitec, 1989).

${ }^{11}$ Armando Magalhães Corrêa, O Sertão Carioca (Rio de Janeiro: Imprensa Nacional, 1933).

${ }^{12}$ Claudia Gaspar and Carlos Barata, De engenho a jardim. Memórias históricas do Jardim Botânico (Rio de Janeiro: Editorial Capivara, 2008).

${ }^{13}$ Maria da Conceição Beltrão, et al., “Arqueologia histórica do Parque Nacional da Tijuca," Clio Arqueológica 1 (1997): 99-108.
} 
and the communication between the central area and the LRF basin was still precarious, rendering a harder occupation process. It was not until 1810 that the government improved the roads connecting both basins. The increase in population demand of natural resources coupled with the improved road conditions stimulated even more the natural resource use, especially for firewood and charcoal production. ${ }^{14}$

During the $19^{\text {th }}$ century, coffee plantation (Coffea arabica L.) became an important economic activity in the emerging city. The more humid and mild weather of the southern facing slopes of Tijuca Massif was favorable for coffee production. This crop demanded a great amount of sunlight and therefore deforestation took place in the highest and most favorable portions of the basin - excluding the steepest terrains-, affecting the geohydrological balance of the Massif and causing massive soil erosion. These processes triggered a crisis on the city's water supply. As an emergency measure, the imperial government expropriated private lands for reforestation. In 1861 the reforestation started with native and exotic species -, and by 1890, 130,000 seedlings had been planted, covering 170 hectares. $^{15,16}$ The result of this assisted regeneration effort ended up in the creation of "Tijuca and Paineiras Forest", considered as the first protected area in Brazil. ${ }^{17}$ Thus, the landscape at the end of $19^{\text {th }}$ century was a mosaic composed by abandoned and semiabandoned croplands, forest restoration areas and reminiscent native forest patches.

At the end of $19^{\text {th }}$ century, Rio de Janeiro had a significant increase in population, promoting a higher rate of occupation in the basin due to an improved network of communication and transportation like the bonde (tram) lines, moved first by mules and then by electricity. The establishment of textile factories in 1884 further boosted its occupation and demand for resources. ${ }^{18}$ During this period, the city's energy matrix was still based on charcoal, with portions of the Serra da Carioca still representing one of the main sources for energy production. The production was done in situ in the forest, through a process that involved a dissection of the slope to produce a level ground of about $45 \mathrm{~m}^{219}$. The vestiges of this practice can be found today hidden in the landscape, as shown in the following section.

At the beginning of the $20^{\text {th }}$ century, with the increasing population, the carioca culture (original from Rio de Janeiro), more specifically the more affluent portion of the carioca society, shifted its attention to the city's oceanfront increasing the estate value of lands within the basin, becoming the most expensive and economically rich zone in the city. Up to this point Rio's south coast and beaches were viewed as "sandy deserts with little land value" ${ }^{20}$, a clear reference to the sand dunes covered by a vegetation known as restinga (herbaceous and shrubby vegetation occurring on poor very well drained sandy soil), that have limited agricultural potential (hence the aforementioned lack of value). However, with new tramlines connecting the oceanfront areas of the basin coupled with increasing urbanization pressures, led to a housing boom and land speculation. Areas of sand dunes and restinga were rapidly transformed into the current high value residential neighborhoods of Leblon and Ipanema, with significant portions of the LRF being landfilled to gain space, and also channelizing the

\footnotetext{
${ }^{14}$ Mauricio Abreu, Evolução urbana do Rio de Janeiro, 2013.

${ }^{15}$ Fuad Atala, "Histórico," in Floresta da Tijuca, Centro de Conservação da Natureza (Rio de Janeiro: Secretaria de Estado de Economia, 1966).

${ }^{16}$ Rogério Oliveira, "Terras cançadas e mattas estragadas": uma pequena história ambiental das chuvas e florestas do Rio de Janeiro," in Águas Urbanas: A Regeneração Ambiental como Campo Disciplinar Integrado, org. Vera Tângari et al. (Rio de Janeiro: FAPERJ/PROARQ-FAUUFRJ/Minister Editora, 2007), 57-77.

${ }^{17}$ Rodrigo Medeiros, "Evolução das tipologias e categorias de áreas protegidas no Brasil,"Ambiente e Sociedade 9 (2006): 41-64.

${ }^{18}$ Mauricio Abreu, Evolução urbana do Rio de Janeiro, 2013.

${ }^{19}$ Armando Magalhães Corrêa, O Sertão Carioca, 1933.

${ }^{20}$ Alberto Lamego, O homem e a Guanabara (Rio de Janeiro: IBGE, 1964).
} 
natural connection between the lagoon and the ocean. As a consequence of these landscape transformations in the last 80 years, on the one hand, the coastal vegetation was almost lost, and on the other, the proximity to forested areas became highly valorized as a part of the current culture that praises nature as a.commodity and also being used for recreational purposes, especially in the Tijuca National Park.

\section{(2) Deciphering, through material evidence of past human uses}

Since natural resources is one of the main drivers for initial land use and occupation, working within a hydrological basin framework is ideal to link the different social actors interacting with the available resources throughout a historical process. In this sense the landscape reading is carried out through the connection of the availability of resources, their distribution in the landscape and most of all in what way the process of human usage of these resources and occupation of the basin occur. The interplay of human occupation and land use with the physical and ecological elements should be interpreted as a socioecological complex system, with a long legacy of human modification imprinted in the landscape.

In urban forested landscapes that have a complex mixture of built up area and forest, one must perceive the landscape through the lenses of the initial settlers, and what type of material culture they had. A comprehensive land use /land cover map is essential to understand what type of environments have been used and occupied and what has been left alone or been abandoned. Historical landmarks, such as old farmhouses that have been preserved, are a good starting point to understand the historical process of land use and occupation.

The main hints and material evidence related to the different historical periods of land use and occupation of the LGF basin are synthesized in Table 1. In the case of the LRF basin, occupation and land use started from the lowlands up the slopes of the Serra da Carioca and other isolated hills (such as Morro dos Cabritos). Part of the historical evidence is present in the current urban area, at the foothills of the Carioca sierra such as old farmhouses, aqueduct ruins, an old chapel, gunpowder house, the workers' housing from the factory. It has been well understood that initial human establishment of a novel space, follows some general rules. Lowland areas are ideal for establishment of the first residences, strategically located close to fresh water sources. ${ }^{21}$ After the initial establishment in lowland areas, the general pattern of human occupation follows upslope and along the main watercourses and drainage axes, since water is one of the most limiting resources for general subsistence and for farming.

Currently, the main trails that lead to touristic sites (waterfalls, scenic views etc.) are starting points for investigating these hidden clues in the landscape, especially since that in the past they provided a network of trails and roads used for the transportation of farm goods and natural resources to the city's central area. An initial assessment revealed fifteen charcoal manufacturing sites (Figure 3) distributed in the sierra da Carioca landscape, showing an intense use of this resource beginning in the $18^{\text {th }}$ century and probably continuing as far as early $20^{\text {th }}$ century, after it had already been banned due to the water shortage Rio went through in the XIX century. This evidence of charcoal production in the forest together with the historical documentation of wood and firewood exploitation from the forested slopes, upland from the farmlands, used for the sugarcane production process

\footnotetext{
${ }^{21}$ Erle Ellis and Navin Ramankutty, "Putting people in the map: anthropogenic biomes of the world," Frontiers of Ecology and the Environment 6 (2008): 439-447.
} 
throughout the $16^{\text {th }}-18^{\text {th }}$ centuries, indicates a profound process of natural resources use from the forest. However the process of charcoal production and wood exploitation does not involve clear cutting, due to the high demand in time and energy to fell and cut down to size trees larger than approximately $35 \mathrm{~cm}$ of diameter. ${ }^{22}$ The maintenance of large remnant trees is one of the reasons of the rapid velocity in forest regeneration after these past uses ended. This can be understood as landscape memory of the previous forest structure retained in the remnant trees. Other physical evidence of landscape modification includes aqueduct ruins used to capture water from the mountainous areas to the farmlands in the lowland areas.

Conducting interviews with the local population, especially to the elder, is of great help to find hints for the interpretation of material evidences. The long term interactions of the inhabitants with the environment provide useful information to enrich the heritage of knowledge needed to read the landscape.

Table 1 - Main landscape transformations of the Lagoa Rodrigo de Freitas basin, summarizing the information found from the three steps proposed, indicating the clues that can be found in the current landscape. Source: own elaboration.

\begin{tabular}{|c|c|c|c|}
\hline Historical period & Social agent & Main activity & Evidence in the landscape \\
\hline $\begin{array}{l}\text { Until early } 16^{\text {th }} \\
\text { century }\end{array}$ & $\begin{array}{l}\text { Sambaquis and } \\
\text { Tubinambás }\end{array}$ & $\begin{array}{l}\text { Agriculture; fishing; } \\
\text { gathering; hunting }\end{array}$ & $\begin{array}{l}\text { Vestiges of use of shells, rests of } \\
\text { rudimentary pottery }\end{array}$ \\
\hline $\begin{array}{l}16^{\text {th }}-18^{\text {th }} \\
\text { centuries }\end{array}$ & $\begin{array}{l}\text { Landowners of } \\
\text { sugar cane mills, } \\
\text { large slave } \\
\text { population }\end{array}$ & $\begin{array}{l}\text { Sugar cane plantation } \\
\text { and production of sugar } \\
\text { and cachaça, livestock } \\
\text { raising, subsistence } \\
\text { agriculture (basic crops } \\
\text { for inhabitant } \\
\text { maintenance) }\end{array}$ & $\begin{array}{l}\text { Vestiges of mills, antique residences } \\
\text { (chácaras), remains of bottles, } \\
\text { charcoal production sites (carvoarias), } \\
\text { ancient fig trees }\end{array}$ \\
\hline $19^{\text {th }}$ century & $\begin{array}{l}\text { Portuguese } \\
\text { Empire, coffee } \\
\text { producers, textile } \\
\text { factories, } \\
\text { charcoal. } \\
\text { producers (ex- } \\
\text { slaves) }\end{array}$ & $\begin{array}{l}\text { Foundation of a } \\
\text { gunpowder factory, } \\
\text { botanical garden, coffee } \\
\text { production, textiles } \\
\text { manufacturing }\end{array}$ & $\begin{array}{l}\text { Dense populations of jackfruit (used } \\
\text { for ornamental and as food resource) } \\
\text { ancient fig trees, ritualistic and } \\
\text { ornamental species, rests of bottles, } \\
\text { charcoal production sites (carvoarias), } \\
\text { ancient aqueducts, chácaras }\end{array}$ \\
\hline $20^{\text {th }}$ century & $\begin{array}{l}\text { Increasing urban } \\
\text { population }\end{array}$ & $\begin{array}{l}\text { Accelerated urbanization } \\
\text { process, land speculation } \\
\text { and increasing } \\
\text { oceanfront land value; } \\
\text { proximity, appreciation } \\
\text { and commodification of } \\
\text { nature (forested areas) }\end{array}$ & $\begin{array}{l}\text { Clumped distribution of } \\
\text { aforementioned exotic species, } \\
\text { modification of native species } \\
\text { assemblages, landfills, perfect straight } \\
\text { lines on the border of the lagoon } \\
\text { (indicating the landfills), canals, } \\
\text { modern constructions (active and } \\
\text { ruins) }\end{array}$ \\
\hline
\end{tabular}

\section{(3) Deciphering current ecological change, through species composition}

The third layer of this landscape reading methodology requires not only good knowledge of the natural history of the landscape, but a sound understanding of geomorphology, biogeography and ecology, that includes, but is not limited to, observation and interpretation of landscape physical features (general land form) and on site species identification that are connected through biogeographical and ecological interpretation. In other words, specific knowledge of these fields, acute observation and time invested in the field are necessary requirements to undergo this third step.

\footnotetext{
${ }^{22}$ Gabriel Paes da Silva Sales et al., "Resultantes ecológicas, práticas culturais e provisão de lenha para a fabricação de carvão nos séculos XIX e XX no Rio de Janeiro". Pesquisas. Botânica, 65 (2014): 389-402.
} 
After a detailed overview of the landscape of the LRF basin, we noticed some general patterns of species composition related to specific land features, and land use history. A close attention to the plants species occurring in the area reveal a diverse array of exotic species used in Afro-Brazilian religious rituals, occurring especially in forest borders and along trails and roads, such as: comigo-ninguém-pode (Dieffenbachia seguine Jacq. Schott.), espada-de-são-jorge (Sansevieria trifasciata Hort. ex Prain), abre-caminho (Lygodium volubile Sw.), and pau-d'água (Dracaena fragrans (L.) Ker Gawl.). ${ }^{23}$ It is also noticeable small and aggregate populations of herbaceous ornamental species, indicating proximity to previous and current human habitations of which trapueraba (Tradescantia zebrina Heynh. ex Bosse) and syngonium (Syngonium podophyllum Schott) stand out. There are also a number of exotic fruit species, such as avocado (Persea americana (Mill.), mango (Mangifera indica L.), laranja-da-terra (Citrus aurantium L.) among other, peppered throughout the Atlantic Forest of the Tijuca Massif, indicating former orchards and managed lands of chácaras from the $18-19^{\text {th }}$ centuries.

One of the most notable floristic modifications observed is the aggregate pattern of the jackfruit tree (Artocarpus heterophyllus Lam.) occupying preferably forest borders, trails, water courses and drainage axes indicating a direct link to past land use and human occupation process of the landscape. The jackfruit is an exotic species native to the region encompassing south-southeast Asia and Oceania, and was part of an agricultural experimentation plan with which the Portuguese crown tried to recover its imperial economy in the late $17^{\text {th }}$ century. ${ }^{24}$ One of the first shipments to Brazil came on the vessel São Francisco Xavier, which arrived in Salvador in 1683, bringing 35 to 40 seedlings, together with instructions for planting.$^{25}$ In addition, as it does not oxidize in contact with metals, jackfruit timber was suitable for the manufacture of the curved pieces that made up the skeleton of the vessels. ${ }^{26}$ Nevertheless, the species became popular essentially as a yard and garden tree. In addition to being visually unique and interesting, it also served as a windbreak. ${ }^{27}$ The jackfruit became very common in chácaras, summer residences that rural nobles and wealthy merchants kept on the outskirts of the city, including the LRF basin, at the foothills of the Serra da Carioca and upper portions of the Gávea valley (Figure 1).

From a total of 54 verification points in the Serra da Carioca, 18 points presented a jackfruit tree cover higher than $50 \%$. This constitutes a spatial pattern of dominance (on the local scale), modifying forest structure by homogenization of canopy architecture and simplification of forest stratification and forest composition by locally reducing species diversity. It also alters the recruitment patterns since the jackfruit trees compete with other species by producing a large number of fruits and seeds, colonizing the immediate space beneath the mother tree, creating a seedling bank and a clumped distribution pattern. ${ }^{28}$ Its distribution capacity is limited by its dispersion syndrome of barochory that is, being dispersed by gravity not far from the tree due the size and weight of the jackfruit. However, it

\footnotetext{
${ }^{23}$ Rogério Oliveira and Inês Machline, "História da paisagem e paisagem sem história: espécies exóticas e nativas manejadas na Mata Atlântica," in Saberes e usos de plantas: legados de atividades humanas no Rio de Janeiro, org. Ariane Peixoto and Inês Machline (Rio de Janeiro: Editora Puc-Rio, 2011).

${ }^{24}$ Nyree Zerega, Nur Supardi and Timothy Motley, "Phylogeny and Recircumscription of Artocarpeae (Moraceae) with a Focus on Artocarpus," Systematic Botany 35 (2010): 766-782.

${ }^{25}$ Philomena Anthony, Relações intracoloniais: Goa-Bahia, 1675-1825 (Brasília-DF: Fundação Alexandre de Gusmão, 2013).

${ }^{26}$ Lucy Hutter, Navegação nos séculos XVII e XVIII. Rumo: Brasil (São Paulo: Editora da Universidade de São Paulo, 2005).

${ }^{27}$ Manuel Pio Corrêa, Dicionário das plantas úteis do Brasil e das exóticas cultivadas (Rio de Janeiro: Instituto Brasileiro de Desenvolvimento Florestal, 1984).

${ }^{28}$ Rodolfo Abreu and Pablo Rodrigues, "Exotic tree Artocarpus heterophyllus (Moraceae) invades the Brazilian Atlantic Rainforest” Rodriguésia 61,(2010): 677-688.
} 
has a strong tendency to roll downhill, concentrating along drainage axes and thus explaining the observed pattern aforementioned. Other modification caused by this high dominance pattern include changes in litter composition, altering nutrient cycling, and modification of inter-species relations, an extremely important component of ecosystem functioning and community structuring, that is very difficult to quantify, since most of the subtle and intricate relations among species are scarcely known. These changes in ecosystem structure and functionality represent a significant difference from historical ecosystems present in the region (high native species diversity with low densities) and may have surpassed socioecological barriers, impeding a return to an "original" or historical state. This transformation configures what current restoration ecology theory classifies as "emerging ecosystems". These novel ecosystems are a consequence of land previously used but which eventually left the sphere of direct and intensive human management, acquiring the ability to self-organize and evolve in unprecedented directions, parenting novel species compositions and assemblage patterns unprecedented in the history of the biome, altering ecosystem functioning. ${ }^{29}$ The remaining 36 verification points revealed a jackfruit tree cover lower than $50 \%$, and thus constituting hybrid communities, with the coexistence of native and exotic species.

Since this species has a long history of human usage and value, being incorporated in the restoration of the Tijuca forest, it is questionable the management practices that have been adopted of felling and bark ringing (of an estimated amount of 2,400 trees). It is very likely that the tracts of forest dominated by this species offer important ecosystem services such as carbon sequestration, dense canopy cover and hence soil erosion contention, enhancing hydrological functionality of the landscape. Not to mention the fact that it serves as resource for many animal species. Furthermore it is also a part of the diet of many lower income households that live in direct contact or close the urban forest. This species has been in the Tijuca forest for 200 years, and is here to stay, together with the colonizers that -introduced it for specific reasons, being part of the complex socioecological system that is the city of Rio de Janeiro.

Another noticeable clue embedded in the species composition is the frequent occurrence of large remnant trees $(\mathrm{DBH}>75 \mathrm{~cm})$. Not uncommon in the secondary forest tracts are large specimens of fig trees (Ficus spp.) that due to cultural practices of religious background where spared from felling, altering successional structuring of the community, creating a natural nucleation site for forest regeneration after the abandonment of the previous land use (agriculture, firewood, charcoal production, coffee plantation). ${ }^{30}$ The spatial pattern of this species can be seen in Figure 1. Other species that were spared from felling include Brazilian cedars (Cedrela fissilis Vell. and Cedrela odorata L.) and jequitibás (Cariniana estrellensis (Raddi) Kuntze, and Cariniana legalis (Mart.) Kuntze). Large specimens of these species would be spared due to a natural respect for the sheer dimension of the tree, or simply for practical reasons, since felling and using these large trees was considered counterproductive by charcoal and banana producers. ${ }^{31}$

\section{Discussion: interpreting Lagoa Rodrigo de Freitas landscape}

Rio de Janeiro is composed of a series of complex and heterogeneous landscapes. From the urban built-up setting towards the hilly portions of the city the gradient of human

\footnotetext{
${ }^{29}$ Ariel Lugo, "The emerging era of novel tropical forests," Biotropica 41 (2009): 589-591.

${ }^{30}$ Alexandro Solórzano, Rogério Oliveira and Rejane Guedes-Bruni, "Geografia, história e ecologia: criando pontes para a interpretação da paisagem," Ambiente e Sociedade 12 (2009): 49-66.

${ }^{31}$ Gabriel Sales et al., Resultantes ecológicas, práticas culturais e provisão de lenha, 2014.
} 
occupation varies from dense to scarce with tall buildings being replaced by small houses, and large avenues by small roads, until the border of the forest is reached only revealing some vestiges of past and current use. Many times forest borders are unique settings, composed of few early succession and exotic species, that persisting through its own dynamics, free of human management, configure emerging border ecosystems. Historical documents and oral history allows for a more in depth comprehension of past and current land uses and human occupation interacting with the forest. A series of pre-existing paths and trails are an indication of past activities such as agriculture or charcoal production, dating back to the 18th and 19th centuries when the forest was used for its natural resources, with the products being transported through mule trails. Along these trails, we have identified past charcoal production sites, indicated by changes in landscape feature, as plateaus do not naturally occur in mountainous terrain, and confirmed by the evidence of charcoal kilns beneath the leaf litter. Exotic arboreal species, embedded in the forest structure, such as the jackfruit (Artocarpus heterophyllus L.) offers further evidence of past human occupation. Further landscape reading includes interpreting the presence of large remnant trees in previously managed forest, some of symbolic importance (such as fig trees) and the presence of ruins (ancient roads, bridges, water catchment, houses, from 18-20th centuries).

Thus this complex landscape will be better interpreted when the physical evidence and floristic evidence is connected to physical features of the landscape such as proximity to water sources (small drainage systems), trails and roads and to current occupation patterns. Mapping these patterns of physical and floristic evidence, allow for a better comprehension of the dynamic interplay of human use of current forested landscapes. This framework sheds some important light on the environmental history of the city connecting urban development with the forest through processes of socioecological metabolism of energy demand and use $^{32}$. Furthermore, this landscape reading method can be helpful for park and city managers enabling a more complex view of the human presence in urban forests, in order to mediate socioecological conflicts, by giving a broader sense of human use and forest regeneration in different spatial and temporal scales. One of the main challenges is to modify current vegetation classification systems, including the knowledge of human systems embedded within ecosystems, producing novel species assemblages (of natives and exotics) that have an intrinsic importance and socioecological relevance.

\section{Conclusions and further research}

This proposal of landscape reading methodology is fundamentally a multidisciplinary effort. Here we understand the importance of a multi-scalar approach, reading the landscape from a global perspective using GIS and satellite imagery to understand the spatial distribution of the physical, ecological and social elements of the landscape. This establishes an understanding of general patterns of land use and occupation through space and time. Complementary to the global analysis and understanding of the whole basin, we propose entering the landscape through fieldwork investigation, connecting the local, one on one, scale of analysis of specific evidences embedded in the soil, landmarks and floristic composition with the landscape as a whole. This in-and-out approach, from local to landscape levels, is fundamental to establish the necessary connections of where, how and why the landscape transformed through time. However, finding the necessary clues to interpret the landscape requires a deep knowledge of the historical land use process, forest composition and ecological interactions. Moreover, it requires many investigative abilities

\footnotetext{
${ }^{32}$ Rogério Oliveira and Inês Machline, História da paisagem e paisagem sem história, 2011.
} 
such as an acute appreciation for fieldwork, keen observation, curiosity, willingness to talk to local social actors and the elder, and a fair amount of common sense.

The preliminary results shown in this paper reveal a wealth of data and information on environmental history, specifically of the carioca society's relation with the forest, which still needs to be enriched with further investigation. Further research within this methodological proposal in order to understand the complex human-forest interaction in the still growing metropolis, includes: increased GIS mapping quality using better resolution information; a more comprehensive and in depth historical analysis using archival research; a broader scale survey of material and floristic evidence of human use and occupation of the LRF basin; and a comparison with other basins in the city of Rio de Janeiro.

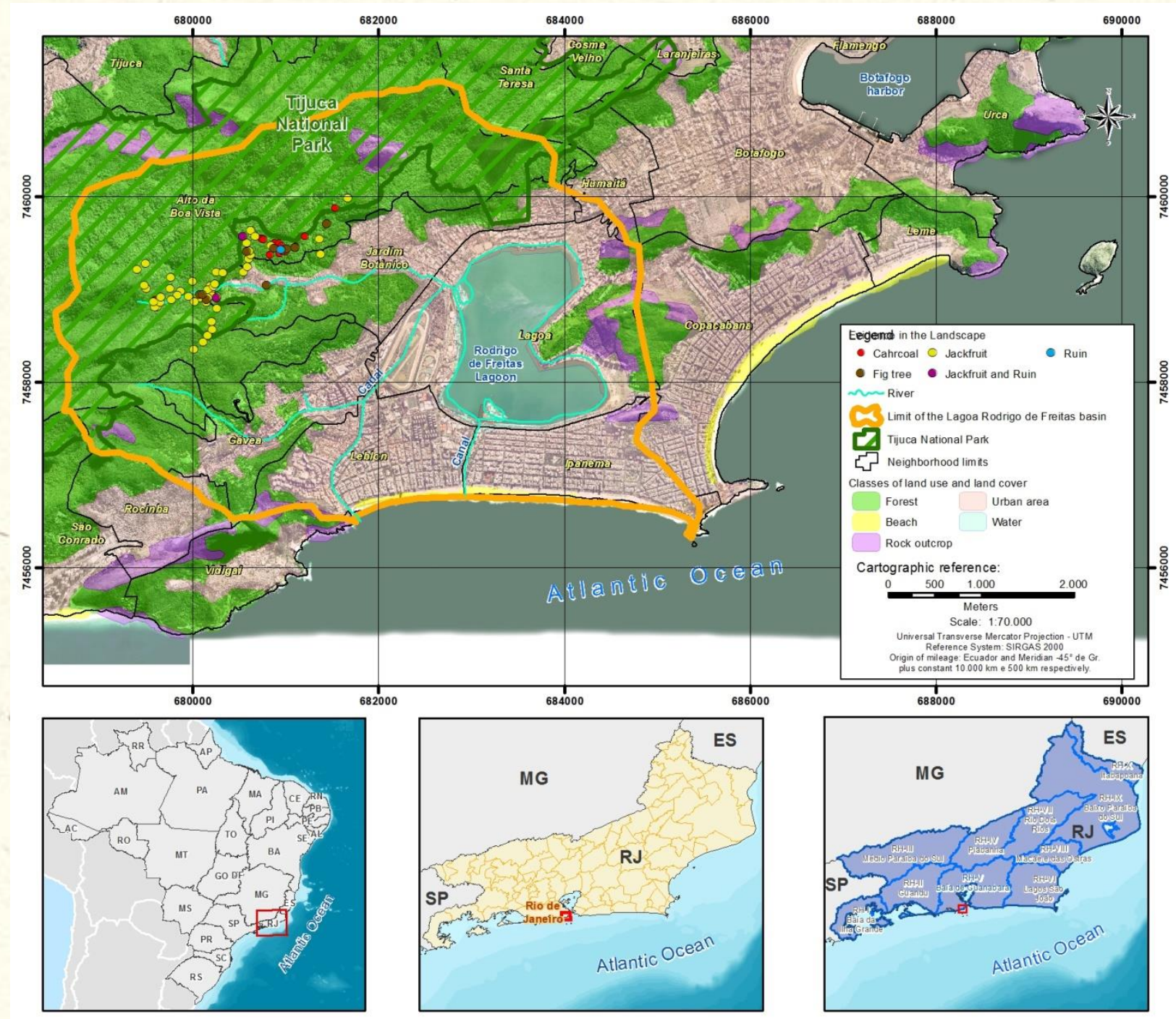

Figure 1 - Land use/ land cover map of the Lagoa Rodrigo de Freitas basin, in the city of Rio de Janeiro. Map by Maria Luciene da Silva Lima. 

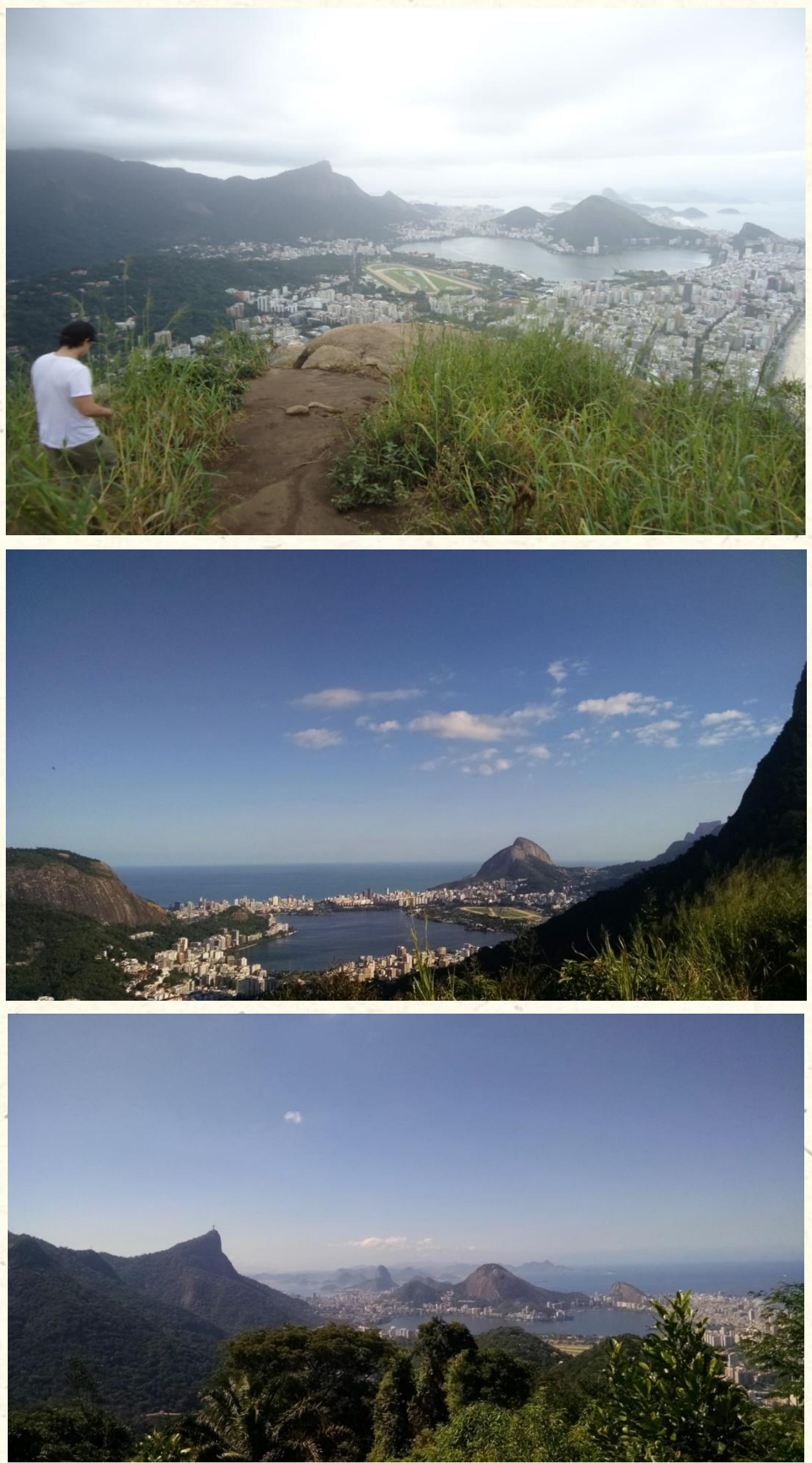

Figure 2 a-c. Digital photographs of the Rodrigo Lagoa de Freitas Basin, viewed from three different perspectives: (a) View from the top of the Morro Dois Irmãos (facoidal-gneiss monolith); (b) View from the Serra da Carioca, Mirante Dona Marta, Tijuca National Park; (c) View from Vista Chinesa, Tijuca National Park. Photos by Alexandro Solórzano. 


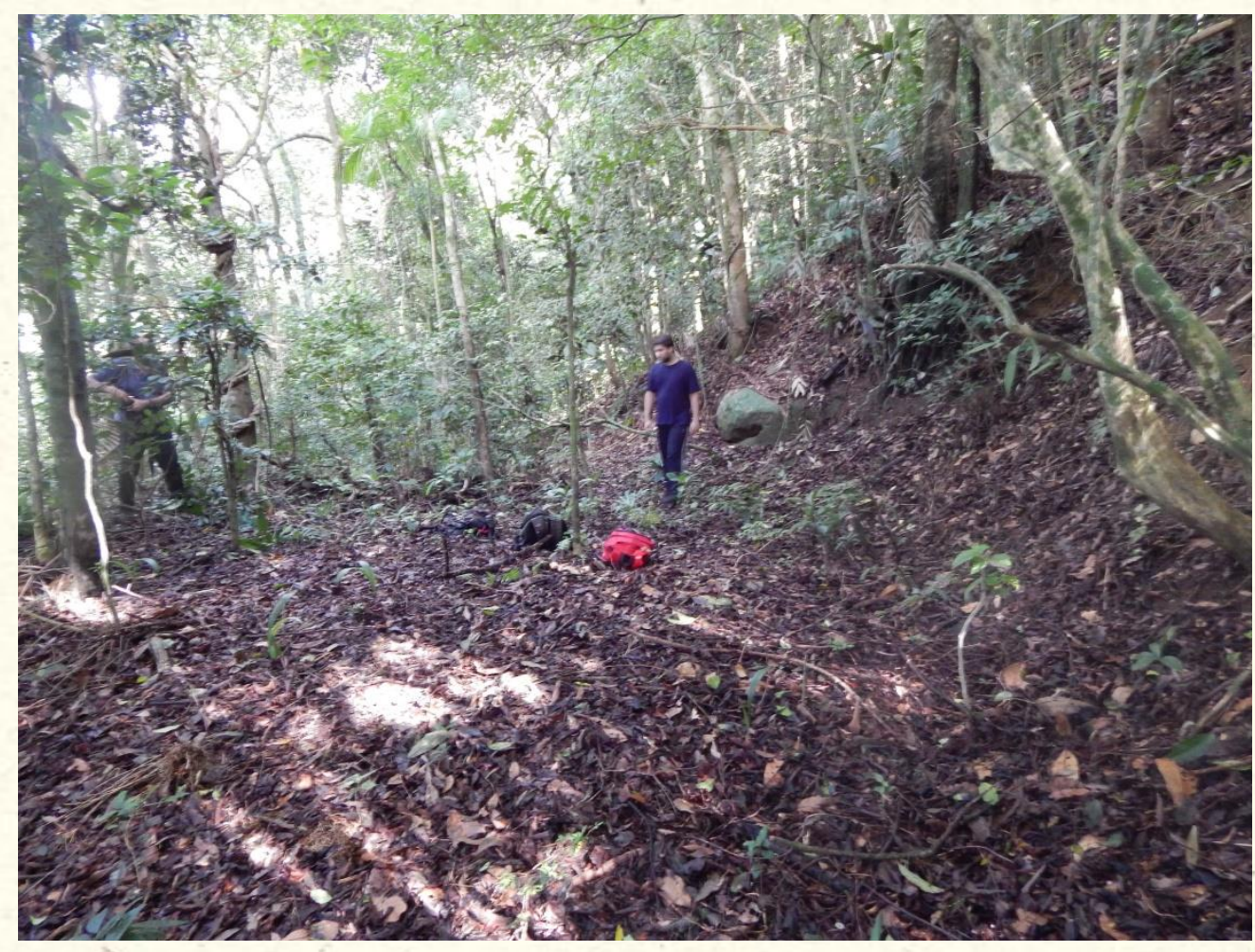

Figure 3 - Plateau used for charcoal production. Photo by Adi Lazos. 
Figure 3 - Plateau used for charcoal production. Photo by Adi Lazos. 